\title{
AN EVALUATION OF THE TECHNICAL EFFICIENCY OF CULTURAL INSTITUTIONS IN POLAND: A CASE STUDY OF THE REGIONAL SYSTEM OF PUBLIC LIBRARIES
}

The political transformation of 1989, as well as Poland's accession to the European Union in 2004, had a significant impact on the cultural sector and the forms of its organisation and funding. These events also contributed to setting new directions for Polish cultural policy. This is a part of a wider public policy, understood as an intentional and deliberate process of achieving objectives in particular areas of public life. Currently, the library policy is an integral component of Polish cultural policy. It aims to achieve specific objectives and implement tasks in the field of the social circulation of library books and the preservation of the linguistic, cultural and civilisational heritage for future generations.

Since 2001, public spending on culture in Poland has remained below $1 \%$ of the total expenditures of the state budget. The limited financial resources earmarked for culture in the national and provincial budgets are the main reasons for performing a comparative study of the technical efficiency of cultural institutions in Poland using the example of libraries. The Polish system of public libraries consists of national, educational, school, medical, agricultural, prison and military libraries. The operations of these institutions require adequate funding to guarantee meeting society's reading and informational needs. The main aim of this paper is to gauge the efficiency of the regional system of libraries in Poland.

The research focuses on analysing the public libraries operating in Polish provinces, using data from Polish Statistical Office resources (The Local Database), and one of the nonparametric methods, i.e. the results-oriented CCR model of data envelopment analysis (DEA). It was found that the major reason for the lack of efficiency in most Polish libraries is the insufficient amount of local government's financial support combined with the lack of self-financing opportunities for such cultural institutions.

Keywords: culture, cultural economics, data envelopment analysis, libraries, public policy, efficiency

JEL Classifications: C69, H72, Z18

DOI: 10.15611 aoe.2020.2.07

\footnotetext{
* Faculty of Economics and Sociology, University of Lodz.
} 


\section{STATEMENT AND IMPORTANCE OF THE PROBLEM}

\subsection{The organisation and funding of culture in Poland}

The system of cultural institutions currently operating in Poland results from the systemic changes to the economy which started in 1989. These consisted of the regular introduction of elements of decentralisation. It was this process that had the greatest impact on the functioning of the cultural sector, particularly as the decentralisation of public tasks in the field of culture involved the transfer of the majority of these tasks from the state to local government level (Głowacki, Hausner, Jakóbik et al. 2009). Local governments were set up as the direct organisations for establishing, managing and independently financing cultural institutions, while provincial and national cultural institutions remained under state supervision. The primary role of the Ministry of Culture and Art in the management of public libraries was eliminated, as was the supervision of local libraries by provincial public libraries (Czajka 1991).

The acts introduced after 2001 on the functioning of cultural institutions, including public libraries, put in order the principles of these organisation and their activities. Pursuant to these acts, the National Library and local government entities, which may be independent cultural institutions or part of other cultural institutions (Polish Journal of Laws/2011 No. 207, item 1230), are considered to be public libraries. These acts also specified the tasks assigned to these cultural institutions (Polish Journal of Laws/2011 No. 10, item 406), such as the digitalisation of cultural institutions (Polish Journal of Laws/2005 No. 65, item 565), keeping records of library materials (Polish Journal of Laws/2008 No. 133, item 883), archiving documents (Polish Journal of Laws/2011 No. 123, item 698), administration and determining employees' remuneration (Polish Journal of Laws/2005 No. 10, item 565; Polish and Journal of Laws/2012 No. 10, item 1105) and the scope of public funding (Polish Journal of Laws/2009 No. 15, item 1241).

In the Polish model of organising and financing culture, one can classify cultural institutions, including libraries, in terms of their importance. This classification divides cultural institutions into three basic categories: national, regional and local. National institutions, including the National Library, are a high priority in terms of the quality of the services provided. Their prestige also results from the nature of the tasks they perform, i.e. the preservation of cultural heritage for future generations. This group includes some institutions intended to meet basic and higher level needs. Since they should provide highquality services, they receive substantial funds. The aim of regional institutions 
is to meet specific basic and higher level needs of supra-local importance. Local institutions are responsible for providing services to meet the needs of local communities.

The state can support cultural institutions directly and indirectly. Funding cultural institutions directly usually take the form of grants and subsidies. Indirect actions on the part of the state consist of tax relief, ranging from preferential VAT rates to tax reductions and exemptions for private sponsors and subsidising prices (van der Ploeg 2005).

In Poland, the obligation to organise and manage cultural activities remains vested in the supreme and central state administrative bodies, and the Ministry of Culture is the main state administrative body in the field of culture, and it is also a direct organiser of cultural activities for national cultural institutions.

After 1991, besides the Ministry of Culture, the provincial governors and local governments have also participated in the organisation and financing of cultural activities in Poland. Province authorities were authorised to organise the activities of state cultural institutions such as provincial public libraries, art exhibition venues, opera houses, philharmonic orchestras, theatres, and museums until 1998 when the right to organise cultural activities was awarded to the local governments as part of their responsibilities, which consist mainly in managing cultural institutions and local libraries. Despite the inclusion of cultural activities in the tasks of local government, the responsibilities in this area are not specified. This generates serious problems because the cultural life of a given community remains largely dependent on the will and commitment of the local authorities and on the activity of the cultural environment in the region (Przybylska 2007).

The reasons for measuring the performance of libraries are related to their management of resources. Cultural organisations, as well as other institutions, use various resources in order to provide a number of cultural services. It is vital that they optimise the way of using the resources taking into account the objectives to be pursued. The importance of measuring the efficiency of cultural institutions (in this case - libraries) is also significant for the public policy-makers in accordance with the public expenditure.

The main goal of the presented study is to gauge the efficiency of the regional system of libraries by applying a non-parametric technique. Libraries were selected for assessment as an example of a cultural institution for several main reasons. Firstly, because they are the most distinctive example of the concept of cultural dissemination as well as cultural heritage. Secondly, because they also represent a group of institutions which are important from the social point of view. Finally, public libraries in Poland are the kind of institutions which were permanently underfunded in the past and have 
radically changed the profile of their activity in order to survive. The main hypothesis of this paper is that increased expenditure from the budgets of local government entities for libraries and their branches has been translated into their greater efficiency.

The CCR model of DEA is one of the most important ones, next to the super-efficiency model and non-radial efficiency model, from the economic point of view (Guzik 2009). At the same time, the CCR model is frequently used to measure the efficiency of cultural institutions (Bosso and Funari 2004). Vitaliano (1998) modelled the efficiency of 184 public libraries in New York. His work was based on the assumption that the performance of public libraries has an exogenous nature (i.e. it is determined by the demand of users on services of libraries). Sharma, Leung, and Zane (1999) modelled the efficiency of 47 public libraries in Hawaii, and they added the inputs that cannot be influenced by management to conventional variables. Hammond (2002) studied 99 public libraries in the UK and modelled the total and technical efficiency using the basic DEA models. Miidla and Kikas (2009) modelled the technical efficiency of 20 public libraries established by the state in Estonia using the DEA models. De Witte and Geyes (2011) published the results of the evaluation of the technical efficiency of 20 DEA models using the example of 290 Flemish public libraries. Stroobants and Bouckaert (2014) evaluated the efficiency of 79 public libraries in Flanders using DEA and free disposal hull (FHD) models. Li and Yang (2014) defined the efficiency of public libraries in the USA according to aggregate indicators under conditions of 51 states of the USA also using the DEA model. The latter publication seems to be quite relevant to the aims and scope of this paper, in which the efficiency of the libraries in Poland was modelled with the aggregated data of 16 provinces (voivodeships) in Poland. In this research, the result-oriented CCR model was applied.

\subsection{Libraries as an element of public policy}

Public libraries in Poland are basically organised as cultural institutions. State policy, one of the components of public policy, plays a decisive role in determining the scope and direction of the activities of cultural institutions. Generally defined, public policy is understood to be an intentional and purposeful process aiming to achieve goals in different areas of public life and shaped by public authorities and public institutions. The acts discussed above show that the national, regional and local authorities may be the subject of this policy, while the collective needs emerging on the national, regional or local level are the object of this policy (Budyńska and Jezierska 2012). 
The fundamental aim of public policy is to determine the direction and purpose of the activities undertaken to resolve essential social problems, setting the priorities and means for their implementation. These problems are also issues in the implementation of cultural policy, which is a component of general policy and manifests itself in the political authorities' desire to construct tangible and spiritual values (Kieliszewski, Poprawski, Landsberg and Gołek 2009). This means that this policy is connected with the social development strategies and is not autonomous. Moreover, it is seen through a lens of the activities of the state and consists entirely of intentional and organised activities by the state and local government bodies (Krzysztofek 1999). Currently, national regulations and EU instruments support the activities of cultural institutions in Poland.

Library policy is linked to public and cultural policy. According to the general definition, library policy is the sum total of measures undertaken by the relevant authorities for the purpose of influencing the circulation and social acceptance of books and other materials collected in libraries. The main assumption of this policy is the achievement of specific objectives and the implementation of tasks in the field of the social circulation of library books as tools of education, culture, and progress (Wołosz 2002). In a wider sense, library policy is the constant supervision by the state over the improvement of structures; the optimisation of all means, methods and techniques applied to meet the needs of citizens in terms of recordings of thought; as well as the harmonisation of this communication channel with particular areas of public life such as science, education, culture and the national economy (Polish Journal of Laws/2003 No. 24, item 199).

Since 1996, the library policy in Poland has been established by legal acts regulating the matters of public librarianship. The directives introduced by the legislature show that the policy was established by the Council of Ministers (Polish Journal of Laws/2003 No. 24, item 199), but designed and implemented by the Minister of Culture. Apart from the fundamental laws, the provisions of the detailed laws set the rules and procedures for the organisation of public librarianship in Poland, with particular attention given to public libraries. An important role in library policy is played by the National Strategies for Cultural Development. The most recent of them - the National Strategy for Cultural Development for 2004-2020 - takes into account the library policy of the Ministry of Culture in both strategic and financial terms. It shows that public libraries are maintained primarily by public funds and are managed by the public administration.

Public libraries in Poland, organised in the form of cultural institutions, can be divided into public and academic libraries. Public libraries include the 
National Library and libraries belonging to local government entities, with academic libraries constituting a separate category. Academic libraries include (apart from the National Library):

- libraries organised by higher education institutions,

- libraries of the National Academy of Sciences,

- libraries organised by research and development units.

Taking into account the changes introduced in the field of culture after the system transformation, one can notice that their main goal is to establish mechanisms conducive to the rational and efficient management of public funds, to introduce changes to the competences of public administration, to decentralise the management of cultural institutions and increase their autonomy, and to enable private entities to participate in implementing tasks in the field of culture and the arts. Despite the introduction of many changes, cultural policy after the transformation can be viewed as passive and chaotic, due to which culture has passively adjusted to the changes taking place in the country, economy, and society (Głowacki, Hausner, Jakóbik et al. 2009).

\section{METHODOLOGY}

\subsection{Data envelopment analysis (DEA)}

The nonparametric DEA allows for the study of efficiency as an economic category based on models that do not require the prior determination of functional relationships between inputs and outputs. In economic analyses, including research in the field of cultural economics, it is assumed that efficiency is one of the main categories used to describe the conditions, functioning, and development of various economic institutions and entities. In researching the functioning of institutions in the public sector, one should consider organisational and economic efficiency, which are the criteria for assessing the activities of the analysed entity and/or its individual areas. In this sense, efficiency refers to the principle of sound management in terms of performance (the maximisation of outputs) and savings (the minimisation of inputs). To express the relationship between inputs and outputs, three basic numerical formulas expressing efficiency can be proposed (Matwiejczuk 2000):

- the difference between outputs and inputs - a result greater than zero means that the results achieved are greater than the incurred expenses,

- the quotient of outputs and inputs - a result greater than unity means that the incurred expenses are lower than the achieved results, 
- the quotient of the difference between effects and expenditure divided by the incurred expenses, defined as a return on investment (ROI) and expressed as a percentage.

It should be noted that the application of the first two formulas requires the expression of inputs and outputs in the same units of measure. The fulfilment of this condition is often a limitation in performing the relevant empirical research. To manage the problem mentioned above, one can use nonparametric methods (such as DEA).

In the context of this paper, one can consider technical efficiency and efficiency of scale. Technical efficiency is assessed by the ratio of the obtained production value to a certain theoretical maximum value determined by the production function as a criterion. The efficiency of scale means the achievement of a higher value for the ratio of production volume to expenditure as production increases, regardless of the unit prices of the products and expenses incurred (Begg, Fischer and Dornbusch 2005). The above-mentioned definitions indicate its relative character, as the evaluation depends on the following three major factors (Kryk 2003, Kryk 2013):

- the scope of the included effects on the side of inputs and outputs,

- the identification of all the outputs of a particular economic activity,

- the adopted reference criterion for a given portion of inputs and outputs.

As previously mentioned, the DEA variants are being proposed with increasing frequency due to certain limitations resulting from difficulties in expressing inputs and outputs in the same units of measure, as well as the relative nature of the technical efficiency as described in the literature (Shim and Kantor 1998). The main advantage of these methods is the fact that they do not require knowledge of the functional dependence between inputs and outputs and the structure of the proposed models is not adjusted to the empirical data. The basis of this method is the application of mathematical programming methods and the relevant empirical observations which allows for the determination of an efficiency frontier that reflects the shape of a function, describing the position of the analysed objects recognised as the most effective within a homogeneous set of observed units (Guzik 2009). The collection of homogeneous objects includes groups of objects of similar technology represented by a set of production capacity (Charnes, Cooper and Rhodes 1978), which is determined on the basis of the available data (this is considered to be a fundamental defect of the deterministic DEA). The main advantages of this method are:

- no need for parametric specifications of the production function, for both one and many products, 
- applicable in the case of a large amount of expenses incurred and number of products (outputs).

- use of linear programming for the calculation of measurement values.

- values of inputs and outputs may be expressed in different units (invariability of the effectiveness measure).

The application of the mathematical programming method allows for the determination of the shape of the efficiency frontier in terms of the value of the efficiency score resulting from the position of the analysed object. The classical approach adopts the definition of technical efficiency as proposed by Debreu (1951) and Farrell (1957). According to these two authors, the technical efficiency of a given object indicates the relationship between the productivity of the object and the productivity of the most effective unit. The basic point of the DEA is the identification of the so-called efficient frontier in comparison to a set of DMUs (decision making units). All the units located on this frontier are said to be operating at $100 \%$ efficiency, while objects that are below the efficiency frontier are inefficient (efficiency below 100\%). In DEA, weights that maximise efficiency scores are assigned to each DMU (Shim and Kantor 1998).

\subsection{Evolution of DEA application in libraries}

DEA techniques are often used in Poland to assess the technical or allocative efficiency of institutions functioning in various sectors of the national economy, especially those financed by public funds. In contrast, only a few studies on the efficiency of public libraries and other institutions of the cultural sector have been conducted thus far. One of the first papers on the efficiency of public libraries in Poland was a study conducted in 1998 by Osiewalski and Osiewalska (2003), which concerned the assessment of the operational costs of libraries based on microeconomic theories. From the point of view of these theories, a library can be regarded as a production unit that uses specific production factors to manufacture products in the form of services meeting specific social needs. Thus, it is important to objectively assess whether the given prices of the resources and the scale and structure of the services provided (the effect of scale) correspond to the costs incurred. The activities of a library can be assessed in two ways: (1) by comparing the actually generated products with the maximum amount of products that could be achieved with the determined expenditure (analysis of technical efficiency based on the frontier production function), defining the minimum cost at the fixed prices of production; or (2) by comparing the actual costs incurred, with the smallest cost at which it would be possible to obtain the product in question 
(analysis of cost efficiency based on the frontier cost function) defining the minimum cost at given prices for the factors.

In order to estimate the cost efficiency of libraries, one can apply deterministic (e.g. DEA) or stochastic methods (e.g. based on the CobbDouglas stochastic cost function). Stochastic cost/production functions are often called stochastic frontier models (SFMs), which can be used to estimate the potential inefficiency of cost drivers. Aigner, Lovell, and Schmidt (1977), as well as Meeusen and van den Broeck (1977), described the application of these models. Vitaliano (1997) presented the application of the Cobb-Douglas cost function in studies on the cost-effectiveness of libraries.

In the library sector, one of the most important areas is the evaluation of library performance, and efficiency has more meaning and importance for the decision-makers at the parent institution ( $\mathrm{Li}$ and Yang 2014). There are two approaches to evaluate relative efficiency across cultural institutions: parametric and non-parametric. The parametric approach includes simple regression analysis and stochastic frontier analysis (SFA) as the econometric techniques to estimate production and cost functions, while SFA is used to estimate the frontier of a set of functions with different underlying levels of efficiency. DEA can be seen as an extension of the simple techniques of index numbers - it is a non-parametric approach that uses mathematical programming techniques. A detailed classification of these two approaches is presented by Sarafidis (2002). In the rapidly developing research on the efficiency of libraries, three major trends can be discerned. The scope of this research includes assessing the degree of resource utilisation (Morse 1972) and whether users' needs are met (van House and Childers 1993), as well as measuring the cost-efficiency of public and college libraries (DeBoer 1992, Chen 1997).

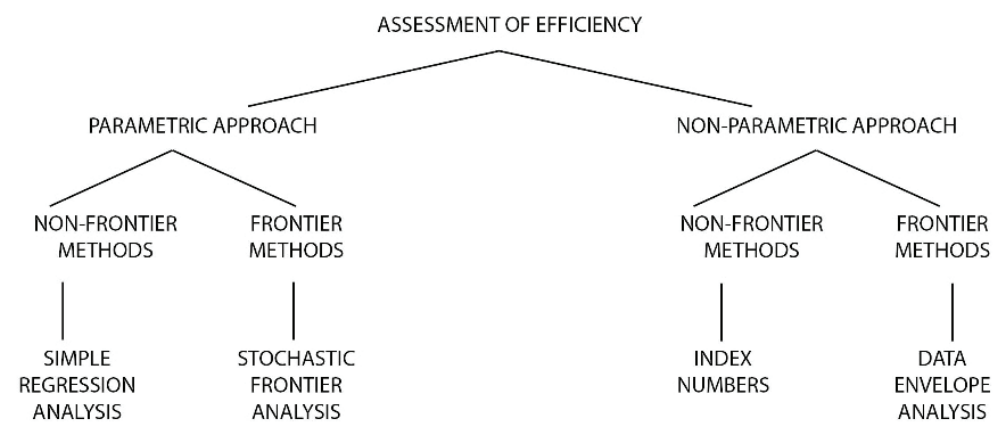

Fig. 1. Taxonomy of efficiency measurement techniques

Source: Sarafidis 2002, p. 3. 
Table 1

Review of input and output variables in international studies on libraries

\begin{tabular}{|c|c|c|c|}
\hline $\begin{array}{l}\text { Author } \\
\text { and year }\end{array}$ & Libraries and country & Inputs & Outputs \\
\hline Kwack 1993 & $\begin{array}{l}20 \text { national University } \\
\text { Libraries in California, } \\
\text { USA }\end{array}$ & $\begin{array}{l}\text { Library staff, area of } \\
\text { library space, number of } \\
\text { library books }\end{array}$ & $\begin{array}{l}\text { Reader visits, circulation of } \\
\text { books }\end{array}$ \\
\hline Chen 1997 & $\begin{array}{l}23 \text { university and } \\
\text { college, non-profit } \\
\text { comparative libraries, } \\
\text { USA }\end{array}$ & $\begin{array}{l}\text { Library staff, book } \\
\text { acquisition expenditure, } \\
\text { area of library space }\end{array}$ & $\begin{array}{l}\text { Reader visits, book circulation, } \\
\text { reference transaction and online } \\
\text { search, interlending service }\end{array}$ \\
\hline Vitaliano 1998 & $\begin{array}{l}184 \text { public libraries in } \\
\text { NY, USA }\end{array}$ & $\begin{array}{l}\text { Total holdings of all items, } \\
\text { total hours of operation } \\
\text { per week, new books } \\
\text { purchased and total serial } \\
\text { subscriptions currently } \\
\text { active } \\
\end{array}$ & $\begin{array}{l}\text { Annual total circulation of all } \\
\text { library materials, in-library use } \\
\text { of materials measured by the } \\
\text { number of reference question } \\
\text { answered }\end{array}$ \\
\hline $\begin{array}{l}\text { Sharma et al. } \\
1999\end{array}$ & $\begin{array}{l}47 \text { public libraries in } \\
\text { Hawaii }\end{array}$ & $\begin{array}{l}\text { Collection, library staff, } \\
\text { days open, non- personal } \\
\text { expenditures }\end{array}$ & $\begin{array}{l}\text { Circulation, reader visits, } \\
\text { reference transactions }\end{array}$ \\
\hline Shim 2003 & $\begin{array}{l}95 \text { academic research } \\
\text { libraries from the } \\
\text { Association of Research } \\
\text { Libraries (ARL), USA } \\
\text { and Canada }\end{array}$ & $\begin{array}{l}\text { Discretionary and } \\
\text { nondiscretionary, } \\
\text { including } 7 \text { discretionary } \\
\text { inputs, } \\
\text { including } 3 \\
\text { nondiscretionary inputs }\end{array}$ & $\begin{array}{l}\text { The total number of interlibrary } \\
\text { lending transaction filled, total } \\
\text { number of interlibrary borrowing } \\
\text { transaction filled, number of } \\
\text { people who participated in group } \\
\text { presentations or instructions, } \\
\text { number of reference transactions } \\
\text { excluding directional questions, } \\
\text { the total number of circulation } \\
\text { including renewals }\end{array}$ \\
\hline $\begin{array}{l}\text { De Carvalho } \\
\text { et al. } 2012\end{array}$ & $\begin{array}{l}37 \text { libraries affiliated to } \\
\text { a federal university in } \\
\text { Rio de Janeiro }\end{array}$ & $\begin{array}{l}\text { Number of employees, } \\
\text { area and number of } \\
\text { volumes }\end{array}$ & $\begin{array}{l}\text { Consultations, loans, enrolments } \\
\text { and user traffic }\end{array}$ \\
\hline $\begin{array}{l}\text { Hwang, Shieh } \\
\text { and Hsieh } \\
2012\end{array}$ & $\begin{array}{l}12 \text { e-resources in } \\
\text { libraries, University of } \\
\text { Taiwan }\end{array}$ & $\begin{array}{l}\text { Target user number and } \\
\text { purchase fee of databases }\end{array}$ & $\begin{array}{l}\text { Connection, searches and } \\
\text { downloads }\end{array}$ \\
\hline
\end{tabular}

Source: Li and Yang 2014, pp. 12-14.

Although the first proposal to utilise DEA was presented by Charnes, Cooper and Rhodes in the late 1970s, the first publications on using DEA techniques to measure the efficiency of libraries appeared only in the 1990s (Li and Yang 2014). Their increased popularity and application was observed only in the last two decades of the twentieth century. It should also be emphasised that increased interest in the results of such research are rooted in the economic slowdown and the reduction of expenditure for operating 
cultural institutions, including public libraries, and the search for effective and efficient tools to support management decisions.

The application of the different effectiveness measurement methods presented in Figure 1 requires specifying a set of input and output variables. The set of values used in DEA allows for the obtaining of relative measures of efficiency, whilst the Malmquist index makes it possible to measure the effectiveness of changes over time and their decomposition.

In papers measuring the efficiency of libraries, different authors defined these two sets of variables and compared them with various institutions and countries. Table 1 presents the results of some research conducted between 1993-2013 (Li and Yang 2014).

The review of the selection of input and output variables presented here shows that the increased number of studies on the efficiency of libraries using the DEA method changed the number of institutions and the scope of their research.

\section{THE RESEARCH}

\subsection{Selection of data and hypotheses}

This study was conducted for public libraries at regional level, applying generally available public data from the Central Statistical Office (GUS) in the period 2003-2014. The selection of the first period of the study was directly conditioned by changes to the organisation and financing of culture in Poland and the completion of local government reform.

In order to use DEA, a non-parametric method of measuring efficiency, it was necessary to adopt a relevant category of inputs and outputs. The following categories were adopted as inputs: the number of libraries (in units) and the amount of funding (in thousands of PLN) that the local government entities allocate from their budgets to libraries.

The following variables were adopted as outputs: book collection (number of books per 1,000 inhabitants of a given province) and the number of readers in the province per 1,000 inhabitants.

In the analysed period, the number of libraries and their branches in Poland decreased by 633, from 8,727 in 2003 to 8,094 in 2014. A similar trend could also be observed in the individual provinces. In the first year of the research, the largest number of public libraries were located in Mazowieckie and Ślaskie provinces, with 1,040 and 845 respectively. The fewest public libraries were recorded in Podlaskie and Lubuskie provinces - 259 and 270 respectively. In 2014, the most and fewest public libraries and their branches were located in 
Table 2

The inputs and outputs for libraries in 2003 and 2014

\begin{tabular}{|c|c|c|c|c|}
\hline \multicolumn{5}{|c|}{2003} \\
\hline \multirow[b]{2}{*}{ State and region } & \multicolumn{2}{|r|}{ Inputs } & \multicolumn{2}{|c|}{ Outputs } \\
\hline & $\begin{array}{l}\text { Number } \\
\text { of libraries } \\
\text { (in units) }\end{array}$ & $\begin{array}{c}\text { Amount } \\
\text { of funding } \\
\text { (in PLN thousand) }\end{array}$ & $\begin{array}{l}\text { Book collection } \\
\text { (per } 1000 \\
\text { inhabitants) }\end{array}$ & $\begin{array}{c}\text { Number } \\
\text { of readers } \\
\text { (per } 1000 \text { inhabitants) }\end{array}$ \\
\hline POLSKA & 8727 & 683579 & 3514,9 & 198 \\
\hline DOLNOŚLĄSKIE & 674 & 53395 & 3707,0 & 224 \\
\hline KUJAWSKO-POMORSKIE & 475 & 31674 & 3711,7 & 184 \\
\hline LUBELSKIE & 627 & 40387 & 3229,7 & 211 \\
\hline LUBUSKIE & 270 & 16623 & 3890,0 & 209 \\
\hline ŁÓDZKIE & 575 & 42088 & 3425,2 & 184 \\
\hline MAŁOPOLSKIE & 773 & 50042 & 3257,1 & 218 \\
\hline MAZOWIECKIE & 1040 & 107092 & 3190,7 & 178 \\
\hline OPOLSKIE & 326 & 17710 & 3973,5 & 171 \\
\hline PODKARPACKIE & 704 & 33951 & 4191,1 & 204 \\
\hline PODLASKIE & 259 & 17779 & 3612,8 & 162 \\
\hline POMORSKIE & 357 & 34281 & 2780,7 & 175 \\
\hline ŚLĄSKIE & 845 & 98176 & 3552,3 & 232 \\
\hline ŚWIĘTOKRZYSKIE & 304 & 18254 & 3394,3 & 170 \\
\hline WARMIŃSKO-MAZURSKIE & 356 & 25830 & 3821,7 & 199 \\
\hline WIELKOPOLSKIE & 752 & 64279 & 3524,8 & 192 \\
\hline ZACHODNIOPOMORSKIE & 390 & 32018 & 4172,6 & 201 \\
\hline \multicolumn{5}{|c|}{2014} \\
\hline & \multicolumn{2}{|r|}{ Inputs } & \multicolumn{2}{|r|}{ Outputs } \\
\hline State and region & $\begin{array}{c}\text { Number } \\
\text { of libraries }\end{array}$ & $\begin{array}{c}\text { Amount } \\
\text { of funding } \\
\text { (in PLN thousand) }\end{array}$ & $\begin{array}{c}\text { Book collection } \\
\text { (per } 1000 \\
\text { inhabitants) }\end{array}$ & $\begin{array}{c}\text { Number } \\
\text { of readers } \\
\text { (per } 1000 \text { inhabitants) }\end{array}$ \\
\hline POLSKA & 8094 & 1304664 & 3397,6 & 164 \\
\hline DOLNOŚLA¿SKIE & 607 & 95129 & 3170,9 & 164 \\
\hline KUJAWSKO-POMORSKIE & 423 & 68911 & 3513,2 & 132 \\
\hline LUBELSKIE & 585 & 86131 & 2906,3 & 176 \\
\hline LUBUSKIE & 252 & 32185 & 3614,6 & 151 \\
\hline ŁÓDZKIE & 542 & 71330 & 3461,4 & 156 \\
\hline MALOPOLSKIE & 724 & 97099 & 3252,4 & 195 \\
\hline MAZOWIECKIE & 964 & 218940 & 3290,9 & 180 \\
\hline OPOLSKIE & 316 & 34763 & 3887,4 & 157 \\
\hline PODKARPACKIE & 678 & 63720 & 4071,7 & 162 \\
\hline PODLASKIE & 240 & 43507 & 4020,1 & 122 \\
\hline POMORSKIE & 322 & 63462 & 2359,5 & 163 \\
\hline ŚLĄSKIE & 800 & 173988 & 3599,0 & 179 \\
\hline ŚWIĘTOKRZYSKIE & 269 & 34872 & 3395,3 & 133 \\
\hline WARMIŃSKO-MAZURSKIE & 304 & 45826 & 3186,9 & 145 \\
\hline WIELKOPOLSKIE & 694 & 115359 & 3437,1 & 152 \\
\hline ZACHODNIOPOMORSKIE & 374 & 59442 & 4049,2 & 150 \\
\hline
\end{tabular}

Source: own calculations, Local Database of the Polish Statistical Office (GUS). 
the same provinces as in the first year of the research. There were 964 libraries in Mazowieckie province, 800 in Śląskie province, 240 in Podlaskie province and 254 in Lubuskie province.

Between 2003-2014, the expenditure on public libraries from the budgets of local government entities in Poland grew gradually. In 2003, expenses amounted to PLN 683,579,000 and in 2014 almost doubled to PLN 130,466,000. In 2003, the highest expenditure from the budgets of local government entities was incurred in Mazowieckie (PLN 107,092,000, which represents 15.7\% of total budget expenditure in Poland) and Śląskie (PLN 98,176,000 - 14.4\%) provinces. In the same year, the lowest expenditure from the budgets of local government entities was recorded in Lubuskie (PLN 16,623,000-2.4\%) and Opolskie (PLN 17,710,000 - 2.6\%). In 2014, the highest expenses from the budgets of local government units were incurred in Mazowieckie (PLN 218,940,000 - 16.8\%) and Śląskie (PLN 173,988,000 - 13.3\%) and the lowest in Lubuskie and Opolskie (PLN32,630,000-2.5\% and PLN 185,347,000 $-2.7 \%$, respectively).

In the analysed years, the number of books in public libraries per 1,000 inhabitants in Poland decreased from 3,514.9 in 2003 to 3,397.6 in 2014. In 2003, the largest numbers of books per 1,000 inhabitants were recorded in public libraries of Podkarpackie $(4,191.1)$ and Zachodniopomorskie $(4,172.6)$, while the fewest books were recorded in Pomorskie $(2,780.7)$ and Mazowieckie $(3,190.7)$. In 2014, the largest numbers of books per 1,000 inhabitants were recorded in public libraries and their branches in Podkarpackie $(4,071.7)$ and Zachodniopomorskie $(4,049.2)$, and the fewest in Pomorskie $(2,359.5)$ and Lubelskie $(2,906.3)$. The greatest rate of change in the number of books per 1,000 inhabitants in the analysed period was observed in Podlaskie (11.27). The following provinces could also boast a positive rate of change: Łódzkie (1.06), Mazowieckie (3.14), Śląskie (1.31) and Świętokrzyskie (0.03). The decreases in the number of books per 1,000 inhabitants were noted in public libraries and their branches in Warmińsko-Mazurskie (-16.61), Pomorskie (-15.15) and Lubelskie (-10.01).

In the analysed period, the number of readers in libraries per 1,000 inhabitants in Poland dropped from 198 in 2003 to 164 in 2014, with a rate of change of -17.44. In 2003, the largest numbers of readers in public libraries per 1,000 inhabitants were recorded in Śląskie (232), Dolnośląskie (224) and Małopolskie (218), while the lowest numbers were recorded in Podlaskie (162), Świętokrzyskie (170) and Opolskie (171). In 2014, the largest numbers of readers in libraries per 1,000 inhabitants were recorded in public libraries 
and their branches in Małopolskie (195), Śląskie (179) and Lubelskie (176), while the lowest was recorded in Podlaskie (122), Kujawsko-Pomorskie (132) and Świętokrzyskie (133). The greatest rates of change in the number of readers in libraries per 1,000 inhabitants in this period occurred in Mazowieckie (1.47). This was the only province to record an increased number of readers in libraries per 1,000 inhabitants. The biggest decreases in the number of readers occurred in Kujawsko-Pomorskie (-28.21), Lubuskie (-27.84) and WarmińskoMazurskie (-27.26).

Taking into account the results of the analysis of statistical data on public libraries and their branches, as well as on expenditure from the budgets of local government entities for this purpose, it can be concluded that increased expenditures have not translated into the increased efficiency of these institutions in the analysed period. To estimate the efficiency the resultoriented CCR model of the DEA nonparametric method was used:

$$
\begin{gathered}
g_{i}=\sum_{r=1}^{R} \mu_{r} y_{r i} \rightarrow \min , \\
\sum_{p=1}^{P} v_{p} x_{p i}=1, \\
\sum_{r=1}^{R} \mu_{i} y_{r i}-\sum_{p=1}^{P} v_{p} x_{p i} \geq 0, \\
\mu_{r} \geq 0, v_{p} \geq 0,
\end{gathered}
$$

where $g_{i}$ stands for object $i$ efficiency $(i=1, \ldots, n), \mu_{i}$ for output weight $(r=1, \ldots, R)$ and $v_{i}$ for cost weight $(p=1, \ldots, P)$.

\subsection{DEA research results -2003}

The values of the efficiency ratio $(\Theta)$ for the provinces obtained from an audit using the DEA nonparametric method (result-oriented CCR model) in 2003 show that full efficiency with the given amount of expenditures was achieved only in Lubuskie, for which the $\Theta$ efficiency ratio reached the value of 1 . The remaining provinces with expenditure in 2003 could have increased their outputs. Assuming that the expenses are constant, Mazowieckie could have increased its outputs by up to $354 \%(\Theta=4.54)$ and Wielkopolskie by $204 \%(\Theta=3.04)$. Podlaskie and Opolskie provinces were the closest in terms of achieving the efficiency threshold, and they could have increased their 
effects in relation to expenditure by $3 \%$ and $4 \%$ respectively. The values of the efficiency ratios for the individual provinces and the rank of provinces in the efficiency ratio are presented in Table 4.

Table 3

The efficiency ratios for the individual provinces and the ranking of provinces by the efficiency ratio (2003)

\begin{tabular}{l|c|c}
\hline \multicolumn{1}{c}{$\mathbf{2 0 0 3}$} & \\
\hline DMU name & rank & theta \\
\hline DOLNOŚLASKIE & 11 & 2.3096 \\
\hline KUJAWSKO-POMORSKIE & 8 & 1.84376 \\
\hline LUBELSKIE & 10 & 2.30933 \\
\hline LUBUSKIE & 12 & 1 \\
\hline LÓDZKIE & 13 & 2.41859 \\
\hline MALOPOLSKIE & 16 & 2.74793 \\
\hline MAZOWIECKIE & 3 & 1.53988 \\
\hline OPOLSKIE & 9 & 1.89567 \\
\hline PODKARPACKIE & 2 & 1.03285 \\
\hline PODLASKIE & 7 & 1.58379 \\
\hline POMORSKIE & 14 & 2.82501 \\
\hline ŚLĄSKIE & 4 & 1.25847 \\
\hline ŚWIĘTOKRZYSKIE & 5 & 1.34208 \\
\hline WARMIŃSKO-MAZURSKIE & 15 & 3.04571 \\
\hline WIELKOPOLSKIE & 6 & 1.34661 \\
\hline ZACHODNIOPOMORSKIE & 12 & \\
\hline
\end{tabular}

Source: own calculations, Local Database of the Polish Statistical Office (GUS).

The analysis of slacks in the DEA model used in the research of efficiency of libraries in Poland in 2003 for the facilities with the best results in terms of the efficiency ratio discussed above is as follows. Opolskie should reduce the number of libraries by 38 and increase the number of readers per 1,000 inhabitants by 44 to achieve the efficiency threshold, while Podlaskie should increase its expenditure on libraries by PLN 1,833,000 per 1,000 inhabitants and simultaneously increase the number of readers per 1,000 inhabitants by 33 to achieve full efficiency. 
Table 4

Presentation of slacks in DEA model for the individual provinces (2003)

\begin{tabular}{l|c|c|c|c}
\hline \multirow{2}{*}{ DMU Name } & \multicolumn{2}{c}{$\mathbf{2 0 0 3}$} & \multicolumn{2}{c}{ Outputs } \\
\cline { 2 - 5 } & $\begin{array}{c}\text { Number } \\
\text { of } \\
\text { libraries }\end{array}$ & $\begin{array}{c}\text { Amount } \\
\text { of funding } \\
\text { (in PLN } \\
\text { thousand) }\end{array}$ & $\begin{array}{c}\text { Book collection } \\
\text { (per 1000 } \\
\text { inhabitants) }\end{array}$ & $\begin{array}{c}\text { Number } \\
\text { of readers } \\
\text { (per 1000 } \\
\text { inhabitants) }\end{array}$ \\
\hline DOLNOŚLĄSKIE & 0 & 11899.1 & 1069.72 & 0 \\
\hline KUJAWSKO-POMORSKIE & 0 & 2429.83 & 0 & 29.6633 \\
\hline LUBELSKIE & 0 & 1784.7 & 1574.9 & 0 \\
\hline LUBUSKIE & 0 & 0 & 0 & 0 \\
\hline LÓDZKIE & 0 & 6687.17 & 0 & 0.555472 \\
\hline MALOPOLSKIE & 0 & 2450.97 & 2186.56 & 0 \\
\hline MAZOWIECKIE & 0 & 43062.7 & 498.07 & 0 \\
\hline OPOLSKIE & 38.3443 & 0 & 0 & 44.3376 \\
\hline PODKARPACKIE & 152.549 & 0 & 0 & 41.3393 \\
\hline PODLASKIE & 0 & 1833.23 & 0 & 33.4568 \\
\hline POMORSKIE & 0 & 12301.7 & 739.301 & 0 \\
\hline ŚLA_SKIE & 0 & 46152.2 & 2138.9 & 0 \\
\hline ŚWIETOKRZYSKIE & 7.50839 & 0 & 0 & 15.6 \\
\hline WARMIŃSKO-MAZURSKIE & 0 & 3912.27 & 0 & 8.51096 \\
\hline WIELKOPOLSKIE & 0 & 17980.9 & 98.7223 & 0 \\
\hline ZACHODNIOPOMORSKIE & 0 & 8007 & 0 & 32.3198 \\
\hline
\end{tabular}

Source: own calculations, Local Database of the Polish Statistical Office (GUS).

In the case of provinces ranked last in terms of the efficiency ratio (Mazowieckie, Wielkopolskie and Śląskie), the following should be done in order to achieve the efficiency threshold:

1) Mazowieckie should reduce its expenditure on libraries by PLN 43,062,000 per 1,000 inhabitants and increase the number of books per 1,000 inhabitants by 498 .

2) Wielkopolskie should reduce its expenditure on libraries from the budgets of local government units (per 1,000 inhabitants) by PLN 17,980,000 and increase the number of books per 1,000 inhabitants by 99 .

3) Śląskie should reduce expenditure from the budgets of local government units on culture by PLN 46,152,000 per 1,000 inhabitants and simultaneously increase the number of books per 1,000 inhabitants by as many as 2,138. 


\subsection{Results of DEA research -2014}

The values of the efficiency ratio $(\Theta)$ for the provinces obtained from an audit using the DEA nonparametric method (result-oriented CCR model) in 2014 show that libraries in only two of sixteen provinces (Lubuskie and Podlaskie) were operating on the efficiency frontier. Libraries in the remaining provinces would have to increase their outputs compared to expenditure on public libraries to achieve the efficiency frontier.

Table 5

The efficiency ratios for the individual provinces and the ranking of provinces by the efficiency ratio (2014)

\begin{tabular}{l|c|c}
\hline \multicolumn{1}{c}{ DMU Name } & rank & theta \\
\hline DOLNOŚLĄSKIE & 11 & 2.33096 \\
\hline KUJAWSKO-POMORSKIE & 8 & 1.84376 \\
\hline LUBELSKIE & 10 & 2.30933 \\
\hline LUBUSKIE & 1 & 1 \\
\hline ŁÓDZKIE & 12 & 2.41859 \\
\hline MAŁOPOLSKIE & 13 & 2.74793 \\
\hline MAZOWIECKIE & 16 & 4.53988 \\
\hline OPOLSKIE & 3 & 1.04299 \\
\hline PODKARPACKIE & 9 & 1.89567 \\
\hline PODLASKIE & 2 & 1.03285 \\
\hline POMORSKIE & 7 & 1.58379 \\
\hline ŚLAॄSKIE & 14 & 2.82501 \\
\hline ŚWIECTOKRZYSKIE & 4 & 1.25847 \\
\hline WARMIŃSKO-MAZURSKIE & 5 & 1.34208 \\
\hline WIELKOPOLSKIE & 15 & 3.04571 \\
\hline ZACHODNIOPOMORSKIE & 6 & 1.34661 \\
\hline
\end{tabular}

Source: own calculations, Local Database of the Polish Statistical Office (GUS).

Opolskie, Świętokrzyskie and Pomorskie provinces came highest in the ranking in terms of the efficiency ratio. In order to achieve the efficiency frontier for their libraries (assuming that the expenditure for this purpose remains unchanged) in 2014, the public libraries in these provinces should increase their outputs by 4\% (Opolskie), 14\% (Świętokrzyskie) and 18\% 
(Pomorskie). Mazowieckie, Wielkopolskie, and Śląskie provinces came last in the ranking. Assuming that expenditure on public libraries and their branches remains unchanged, to achieve the efficiency frontier in 2014 the provinces should increase their effects by 221\% (Mazowieckie), 173\% (Wielkopolskie) and 168\% (Śląskie).

Table 6

Presentation of slacks in DEA model for the individual provinces (2014)

\begin{tabular}{|c|c|c|c|c|}
\hline \multicolumn{5}{|c|}{2014} \\
\hline \multirow[b]{2}{*}{ DMU Name } & \multicolumn{2}{|c|}{ Inputs } & \multicolumn{2}{|c|}{ Outputs } \\
\hline & $\begin{array}{c}\text { Number } \\
\text { of libraries }\end{array}$ & $\begin{array}{l}\text { Amount } \\
\text { of funding } \\
\text { (in PLN } \\
\text { thousand) }\end{array}$ & $\begin{array}{l}\text { Book collection } \\
\text { (per } 1000 \\
\text { inhabitants) }\end{array}$ & $\begin{array}{c}\text { Number } \\
\text { of readers } \\
\text { (per } 1000 \text { inhabitants) }\end{array}$ \\
\hline DOLNOŚLĄSKIE & 607 & 95129 & 3170.9 & 164 \\
\hline $\begin{array}{l}\text { KUJAWSKO- } \\
\text {-POMORSKIE }\end{array}$ & 423 & 68911 & 3513.2 & 132 \\
\hline LUBELSKIE & 585 & 86131 & 2906.3 & 176 \\
\hline LUBUSKIE & 252 & 32185 & 3614.6 & 151 \\
\hline ŁÓDZKIE & 542 & 71330 & 3461.4 & 156 \\
\hline MALOPOLSKIE & 724 & 97099 & 3252.4 & 195 \\
\hline MAZOWIECKIE & 964 & 218940 & 3290.9 & 180 \\
\hline OPOLSKIE & 316 & 34763 & 3887.4 & 157 \\
\hline PODKARPACKIE & 678 & 63720 & 4071.7 & 162 \\
\hline PODLASKIE & 240 & 43507 & 4020.1 & 122 \\
\hline POMORSKIE & 322 & 63462 & 2359.5 & 163 \\
\hline ŚLĄSKIE & 800 & 173988 & 3599.0 & 179 \\
\hline ŚWIĘTOKRZYSKIE & 269 & 34872 & 3395.3 & 133 \\
\hline $\begin{array}{l}\text { WARMIŃSKO- } \\
\text {-MAZURSKIE }\end{array}$ & 304 & 45826 & 3186.9 & 145 \\
\hline WIELKOPOLSKIE & 694 & 115359 & 3437.1 & 152 \\
\hline $\begin{array}{l}\text { ZACHODNIO- } \\
\text { POMORSKIE }\end{array}$ & 374 & 59442 & 4049.2 & 150 \\
\hline
\end{tabular}

Source: own calculations, Local Database of the Polish Statistical Office (GUS).

The analysis of slacks for provinces that occupied opposite positions in the ranking of the efficiency ratio in 2014 is as follows:

1) To achieve the efficiency threshold in 2014, Opolskie should reduce the number of libraries by 43 and simultaneously increase the number of readers per 1,000 inhabitants by 6 . 
2) Świętokrzyskie should increase the number of readers per 1,000 inhabitants by 8 without changing expenditure levels.

3) Pomorskie should reduce expenditures on libraries per 1,000 inhabitants by PLN 22,337,000 and at the same time increase the number of books per 1,000 inhabitants by 1,829 .

4) Mazowieckie should increase the number of books per 1,000 inhabitants by 3,276 and simultaneously increase expenditure by PLN 95,819,600.

5) Wielkopolskie should increase the number of books per 1,000 inhabitants by 541 and simultaneously increase expenditure by PLN 26,722,500.

6) In order to achieve the efficiency frontier, Ślaskie should increase the number of books per 1,000 inhabitants by 1,799 and simultaneously increase budget expenditure by PLN 71,813,400.

\subsection{Comparison of DEA results for 2003 and 2014}

Throughout the analysed period the majority of libraries in the individual provinces maintained or increased their technical efficiency. The greatest efficiency in the analysed period was achieved by public libraries and their branches in Lubuskie, which ranked first in the first and last years of the research, with the ratio $\Theta$ for the province amounting to 1 in both years. Podlaskie was ranked second in terms of efficiency. In 2003, it ranked second with the value of the $\Theta$ coefficient amounting to 1.03. In 2014, together with Lubuskie, ranked first with the $\Theta$ coefficient ratio equalling 1 .

The libraries of Mazowieckie, Wielkopolskie and Ślaskie provinces were the least efficient throughout the research period. These provinces ranked 16 th, 15th, and $14^{\text {th }}$, respectively. However, it should be noted that they improved their efficiency in the last year of the research in comparison to the first. For Mazowieckie, the $\Theta$ ratio was 4.54 in 2003 and 3.20 in 2014, in Wielkopolskie these values were 3.04 and 2.74, respectively, and 2.82 and 2.67 , respectively, for Śląskie.

\subsection{Analysis of changes in the productivity of libraries in 2003-2014}

The Malmquist index is employed in order to evaluate changes in productivity between the two periods. To estimate the Malmquist indices, the following formula was used:

$$
M^{t, t+1}\left(x^{t}, y^{t}, x^{t+1}, y^{t+1}\right)=T E\left(x^{t}, y^{t}, x^{t+1}, y^{t+1}\right) \times T C\left(x^{t}, y^{t}, x^{t+1}, y^{t+1}\right),
$$


where $T E$ stands for technical effectiveness change between period $t$ and $t+1$ and $T C$ stands for technological change measured separately for technologies in two different periods - the effectiveness of the object in period $t$ is compared to the technology from period $t+1$ and the effectiveness of the object in $t+1$ period is compared to the technology in period $t$.

Table 7

Malmquist index summary of libraries means by provinces

\begin{tabular}{l|c|c|c|c|c}
\hline \multicolumn{1}{c|}{ Province } & $\begin{array}{c}\text { Technical } \\
\text { efficiency } \\
\text { change }\end{array}$ & $\begin{array}{c}\text { Technological } \\
\text { change }\end{array}$ & $\begin{array}{c}\text { Pure technical } \\
\text { efficiency } \\
\text { change }\end{array}$ & $\begin{array}{c}\text { Scale } \\
\text { efficiency } \\
\text { change }\end{array}$ & $\begin{array}{c}\text { Total factor } \\
\text { productivity } \\
\text { change }\end{array}$ \\
\hline DOLNOŚLA_SKIE & 0.980 & 0.998 & 0.991 & 0.989 & 0.979 \\
\hline $\begin{array}{l}\text { KUJAWSKO- } \\
\text {-POMORSKIE }\end{array}$ & 1.000 & 0.996 & 0.997 & 1.003 & 0.996 \\
\hline LUBELSKIE & 1.001 & 0.989 & 1.002 & 0.999 & 0.990 \\
\hline LUBUSKIE & 1.000 & 0.986 & 1.000 & 1.000 & 0.986 \\
\hline ŁÓDZKIE & 1.000 & 0.991 & 1.006 & 0.994 & 0.991 \\
\hline MALOPOLSKIE & 0.999 & 0.997 & 1.004 & 0.994 & 0.996 \\
\hline MAZOWIECKIE & 1.009 & 0.999 & 1.000 & 1.009 & 1.008 \\
\hline OPOLSKIE & 1.000 & 1.003 & 1.000 & 1.000 & 1.003 \\
\hline PODKARPACKIE & 1.000 & 0.994 & 1.000 & 1.000 & 0.994 \\
\hline PODLASKIE & 1.001 & 1.012 & 1.000 & 1.001 & 1.013 \\
\hline POMORSKIE & 1.012 & 0.990 & 1.009 & 1.003 & 1.002 \\
\hline ŚLALSKIE & 0.985 & 1.000 & 0.999 & 0.986 & 0.985 \\
\hline ŚWIĘTOKRZYSKIE & 0.998 & 0.992 & 1.000 & 0.998 & 0.990 \\
\hline WARMIŃSKO- & 0.997 & 0.989 & 0.994 & 1.003 & 0.985 \\
\hline -MAZURSKIE & 0.996 & 0.992 & 0.999 & 0.997 & 0.988 \\
\hline WIELKOPOLSKIE & 0.993 & 0.997 & 1.000 & 0.993 & 0.990 \\
\hline ZACHODNIO- & 0.998 & 0.995 & 1.000 & 0.998 & 0.993 \\
\hline POMORSKIE & & & & & \\
\hline Mean & & & & & \\
\hline
\end{tabular}

Source: own calculations, Local Database of the Polish Statistical Office (GUS).

In the analysed case, the values of the Malmquist indices for libraries in all of the provinces were approximate to 1 and their average value was 0.993 , which indicates a lack of significant changes in productivity. In libraries in the majority of the provinces, the Malmquist index had a value slightly below 1 (see Table 8), indicating minimal drops in productivity during the research period. 
Table 8

Malmquist index summary of annual means for libraries in 2003-2014

\begin{tabular}{l|c|c|c|c|c}
\hline Year & $\begin{array}{c}\text { Technical } \\
\text { efficiency } \\
\text { change }\end{array}$ & $\begin{array}{c}\text { Technological } \\
\text { change }\end{array}$ & $\begin{array}{c}\text { Pure technical } \\
\text { efficiency } \\
\text { change }\end{array}$ & $\begin{array}{c}\text { Scale } \\
\text { efficiency } \\
\text { change }\end{array}$ & $\begin{array}{c}\text { Total factor } \\
\text { productivity } \\
\text { change }\end{array}$ \\
\hline 2004 & 1.014 & 0.986 & 1.001 & 1.012 & 1.000 \\
\hline 2005 & 1.001 & 0.990 & 1.001 & 1.000 & 0.991 \\
\hline 2006 & 0.998 & 0.977 & 1.000 & 0.998 & 0.976 \\
\hline 2007 & 1.007 & 0.967 & 1.000 & 1.006 & 0.974 \\
\hline 2008 & 0.986 & 1.001 & 0.996 & 0.989 & 0.986 \\
\hline 2009 & 0.991 & 1.009 & 0.998 & 0.993 & 1.001 \\
\hline 2010 & 0.991 & 0.997 & 0.998 & 0.994 & 0.988 \\
\hline 2011 & 0.978 & 1.026 & 1.000 & 0.978 & 1.004 \\
\hline 2013 & 1.005 & 1.014 & 1.004 & 1.001 & 1.019 \\
\hline 2014 & 1.008 & 0.995 & 0.999 & 1.010 & 1.003 \\
\hline mean & 1.002 & 0.986 & 1.003 & 0.999 & 0.987 \\
\hline & 0.998 & 0.995 & 1.000 & 0.998 & 0.993 \\
\hline
\end{tabular}

Source: own calculations, Local Database of the Polish Statistical Office (GUS).

The performance of libraries improved slightly only in Podlaskie, Mazowieckie, Opolskie and Pomorskie provinces, and the TFPC values were $1.013,1.008,1.003$ and 1.002 , respectively.

Analysing the values of the Malmquist index for libraries in Poland in individual years (see Table 9), it can be seen that the greatest drop in production in the analysed cultural entities occurred in 2006 , amounting to $0.26 \%$. The greatest increase in the productivity of libraries took place in 2012 - the value of the Malmquist index reached 1.0019, indicating a $0.19 \%$ increase in productivity compared to the previous year.

The decomposition of the Malmquist indices allows one to determine the sources of these changes in productivity. These include technological changes, technical efficiency changes and pure technical efficiency changes, as well as scale efficiency changes. In the case of libraries, it can be stated that none of these sources of change in productivity were significant during the research period.

\section{CONCLUSION}

The conducted analysis shows that the research hypothesis should be considered as true. Despite a substantial increase in expenditure from the budgets of local government entities in Poland on public libraries and their 
branches between 2003-2014, full efficiency was reached only by Lubuskie (2003 and 2014) and Podlaskie (2014) provinces. The other provinces proved to be inefficient. However, it should be noted that the majority of provinces increased their libraries' efficiency throughout the research period, as evidenced by the declining values of the $\Theta$ ratio.

An analysis of slacks in the research period shows that, with unchanged expenditure and the efficiency measured by the number of readers per 1,000 inhabitants, most provinces achieved maximum effects with an unchanged number of libraries. This means that the number of public libraries and their branches is sufficient to meet the current demand for these types of services. In most public institutions, the biggest slacks occurred in the case of expenditure from the budget of local government units in PLN 1,000 and outputs measured by book collection volume per 1,000 inhabitants. To become efficient, most public libraries and their branches should increase their income and simultaneously increase the number of books per 1,000 inhabitants. Libraries, as a specific type of cultural institutions, have limited opportunities to increase their own income by the implementation of additional services (e.g. the reprography or cafeteria). To become more efficient, libraries need more financial support from local governments.

The performed analysis shows that an increase in expenditure from local government budgets on public libraries and their branches were incommensurate to increases in the technical efficiency of these institutions during this period. This means that the majority of expenses incurred were linked to goals other than the improvement of library reading. These were related to the need to modernise libraries in Poland and incur expenses for their technical infrastructure (computerisation, informatisation, the replacement of furniture and resources, automation of the borrowing and returns processes). Between 2003-2014, there was a decrease in the number of these institutions in Poland, which had no significant impact on their efficiency. The main impediment for public libraries to achieve efficiency was the lack of sufficient expenditure to support books.

In the research period, no changes to the productivity of libraries either in terms of years or in the individual provinces were noted, showing that the values of the Malmquist index varied in the local units.

The DEA analysis estimated the relative technical efficiency of public libraries in Poland irrespective of their quality comparisons. The results provide guidance both for the self-government entities as well as for the libraries. For the regions that do not perform efficiently in terms of public library services the results give a strong indication on how to increase the 
libraries' incomes and the number of books to improve the level of public library services.

Future research is needed to analyse public libraries' technical efficiency at individual level, and to examine how each public library should improve its individual performance with the identification of the impacting factors.

\section{REFERENCES}

Begg, D., Fischer, S., Dornbusch, R., Economics, Eighth Edition. McGraw-Hill Education, Berkshire 2005.

Bosso, A., Funari, S., A Quantitative Approach to Evaluate the Relative Efficiency of Museums, "Journal of Cultural Economics", Vol. 28, No 3, pp. 195-216, 2004.

Budyńska, B., Jezierska, M., Polityka biblioteczna i finansowanie bibliotek publicznych $w$ Polsce [Library policy and financing of public libraries in Poland]. Obserwatorium kultury, Warsaw 2012.

Charnes, A., Cooper, W. W., Rhodes, E., Measuring the efficiency of decision-making units, "European Journal of Operational Research", Vol.2, No 6,pp. 429-444, 1978.

Chen, T., A measurement of the resource utilization efficiency of university libraries, "International Journal of Production Economics", Vol. 53, No 1, 1997.

Czajka, S., Biblioteki publiczne w stużbie społeczności lokalnej. Potrzeby wymiany informacji $i$ doświadczeń [Public libraries services for the local community. Needs to exchange information and experiences], "Bibliotekarz", No 10, p. 4, 1991.

De Witte, K., Geyes, B., Evaluating efficient public good provision: Theory and evidence from a generalised conditional efficiency model for public libraries, "Journal of Urban Economics", Vol. 69, No 3, pp. 319-327, 2011.

Deberu, G., The Coefficient of resource utilization, "Econometrica", Vol. 9, No 3, pp. 273-292, 1951.

DeBoer, L., Economies of scale and input substitution in public libraries, "Journal of Urban Economics", Vol. 32, No 2, 1992.

Farrell, M. J., The measurement of productive efficiency, J Roy Stat Soc, Series A (III), pp. 253-290, 1957.

Głowacki, J., Hausner, J., Jakubik, K., et al., Raport o stanie kultury [Report on the state of culture]. Ministerstwo Kultury i Dziedzictwa Narodowego Warszawa 2009.

Guzik, B., Podstawowe modele DEA w badaniu efektywności gospodarczej i społecznej [Basic DEA models in the study of economic and social efficiency]. Publishing House of Poznan University of Economics, Poznan 2009.

Hammond, C., Efficiency in the provision of public services: A data envelopment analysis of UK public library systems, “Applied Economics”, Vol. 34, No 5, pp. 649-657, 2002.

House, N. A. van, Childers, T. A., The public library effectiveness study: the complete report, Chicago, 1993. 
Kieliszewski, P., Poprawski, M., Landsberg, P., Gołek, P., Projekt przeksztatceń instytucji upowszechniania kultury $w$ Polsce [The project of transformation of institutions popularizing culture in Poland] [in:] Sojka, J., Poprawski, M., Wieliszewski, P. (ed.) Instytucje upowszechniania kultury $w$ XXI wieku. Przeżytek czy nowa jakość? [Institutions popularizing culture in the 21 st century. A relic or a new quality?]. Bogucki-Wydawnictwo Naukowe S.C., Poznan 2009.

Kryk, B., Cost-benefit analysis in the assessment of the environmental and social effectiveness, Research Papers of Wrocław, Wrocław 2013.

Kryk, B., Efektywność ekonomiczno-ekologiczna a cele gospodarowania [Economic and ecological effectiveness and management goals] [in:] Kopycińska, D. (ed.), Państwo i rynek $w$ gospodarce [The state and the market in the economy]. Polskie Towarzystwo Ekonomiczne, Szczecin 2003.

Krzysztofek, K., Ewolucja zalożeń i programów polityki kulturalnej w Polsce $w$ latach dziewięćdziesiatych [Evolution of assumptions and programs of cultural policy in Poland in the nineties] [in:] Kostyrko, T., Czerwiński, M. (eds.) Kultura polska $w$ dekadzie przemian [Polish culture in a decade of changes]. Instytut Kultury, Warsaw 1999.

Li, P., Yang, Z., Performance Evaluation of the Libraries in the USA Using Data Envelopment Analysis, "International Journal of Science and Technology", Vol. 4, No 2. pp. 10-19, 2014.

Matwiejczuk, R., Efektywność - próba interpretacji [Efficiency - an attempt at interpretation], "Przegląd Organizacji”, No 11, p. 7, 2000.

Miidla, P., Kikas, K., The efficiency of Estonian central public libraries, "Performance Measurement and Metrics", Vol. 10, No 1, pp.49-58, 2009.

Morse, P. M., Measures of library effectiveness, "The Library Quarterly”, Vol. 42, No 1, 1972.

Osiewalski, J., Osiewalska, A., Ocena efektywności kosztowej bibliotek akademickich na podstawie danych przekrojowo-czasowych [Assessment of the cost-effectiveness of academic libraries based on cross-sectional data], Zeszyty Naukowe Akademii Ekonomicznej w Krakowie, No 628, 2003.

Ploeg van der, F., The making of cultural policy: an European perspective. CESIFO Working Paper No 1524. Category 1. Public Finance, 2005.

Polish and Journal of Laws/2012 No 10, item 1105

Polish Journal of Laws/2003 No 24, item199

Polish Journal of Laws/2005 No 10, item 565

Polish Journal of Laws/2005 No 65, item 565

Polish Journal of Laws/2008 No 133, item 883

Polish Journal of Laws/2009 No 15, item 1241

Polish Journal of Laws/2011 No 10, item 406

Polish Journal of Laws/2011 No 123, item 698

Polish Journal of Laws/2011 No 207, item 1230

Przybylska, J., Finansowanie działalności kulturalnej w Polsce [Financing cultural activities in Poland]. Publishing House of Poznan University of Economics, Poznan 2007.

Sarafidis, V., An Assessment of Comparative Efficiency Measurement Techniques, "Europe Economics", 2002. 
Sharma, K. R., Leung, P., Zane, L., Performance measurement of Hawaii state public libraries: An application of data envelopment analysis (DEA), "Agricultural and Resource Economics Review”, Vol. 28, No 2, pp. 1990-198, 1999.

Shim, W., Kantor, P. B., A Novel Economic Approach to the Evaluation of Academic Research Libraries. In Proceedings of Information Access in the Global Information Economy, Inf. Today No 35, pp. 400-410, 1998.

Stroobants, J., Bouckaert, G., Benchmarking local public libraries using non-parametric frontier methods: A case study of Flanders, Library and Information Science Research, Vol. 36, No 3-4, pp 211-224, 2014.

Vitaliano, D. F., Assessing public library efficiency using data envelopment analysis, "Annals of Public and Cooperative Economics", Vol. 69, No 1, pp. 107-122, 1998.

Vitalino, D. F., X-inefficiency in the public sector: the case of libraries, "Public Finance Review", Vol. 25, pp. 629-643, 1997.

Wołosz, J., Polityka biblioteczna państwa - oczekiwania i nadzieje [State library policy expectations and hopes], EBIB, 2001.

Received: March 2018, revised: June 2019 